wało mi się, że ceremonie te nie mały nic wspólnego ze wspótczesnym światem, który nas otacza $i w$ którym żyjemy, jak te $\dot{z}$ $z$ problematyka poruszana $w$ czasie naszych debat. Tym razem nic nie zrobiło na mnie takiego wrażenia jak nasze nabożeństwa; podkreślam „nasze” nabożeństwa, bo choć z żalem wyznaję, że nie mogliśmy przystapić razem $z$ wami do Komunii, to łączyliśmy się całym sercem $z$ wami $w$ śpiewach, modlitwach, czytaniach Pisma Swiętego i byliśmy wśród was, podczas waszej modlitwy dziękczynnej po przyjęciu Ciała i Krwi Pana Jezusa. W czasie Kongresu odczuliśmy radość płynaca z uczestnictwa $w$ liturgii Kościoła Chrystusowego. ${ }^{3}$

Paryż

KS. STANISEAW BURZAWA

Ks. Roman Michałek, Itówiec k.Poznania

\title{
WAŻNIEJSZE PRZEPISY ZAWARTE W INSTRUKCJ ŚW. KONGREGACJI OBRZĘDÓW O KULCIE TAJEMNICY EUCHARYSTYCZNEJ Z 25 V 1967 r.
}

Na polecenie Ojca Św. Pawła VI Rada dla realizowania Konstytucji o św. Liturgii opracowała specjalną Instrukcję, której celem jest: całościowe uporządkowanie kultu Eucharystii w oparciu o wszystkie odnośne dokumenty urzędu nauczýcielskiego Kościoła wydane zwłaszcza w ciągu ostatnich dwudziestu lat, podanie ogólnych zasad nauczania o Eucharystii oraz troska o stosowanie jak najbardziej zrozumiałych symboli przy sprawowaniu tego sakramentu, stanowiącego centrum liturgii oraz całego życia Kościoła (por. nr 1, 4 i 6 cyt. Instr.). Opracowany dokument zostal zatwierdzony przez $\mathrm{Pa}-$ pieża 13.IV.1967 r., ogłoszony przez Kongregację Obrzędów w uroczystość Bożego Ciała, 25.V. i opublikowany w Osservatore Romano 31 tegoż miesiąca. Wszedł on w życie $\mathrm{z}$ dniem 15.VIII.1967. Rozpoczyna się od słów „Eucharisticum mysterium”, a oficjalny jego tytuł brzmi: „Instructio de cultu mysterii eucharistici". Liczy aż 67 atykułów i dzieli się (poza wstępem) na trzy części. Wspaniały doktrynalny wstęp przypomina najnowsze dokumenty Kościoła, które mówią o Eucharystii ( $\mathrm{n}$ 1) oraz podaje główne punkty nauki o Najśw. Sakramencie, zawartej w tych dokumentach (nr 3). W cześci I (nr 5-15) są podane pewne zasady ogólne, które trzeba uwzględnić w nauczaniu wiernych. Warto tu przytoczyć np. ważne przypomnienie, że obowiązek uczestniczenia we Mszy św. dotyczy nie tylko Liturgii Eucharystycznej, lecz także Liturgii Słowa oraz, że podczas Mszy św. Chrystus jest obecny rzeczywiście (realiter) i to w czwo-

3 Documentation Catholique, 17.XII.1967, nr 1507, kol. 2164. 
raki sposób: 1) w wiernych, którzy zgromadzili się w jego imię (por. Mt. 18, 20), 2) w słowie, gdy przemawia do nas podczas czytania i wyjaśniania Pisma św., 3) w osobie celebransa i 4) w sposób najwyższy (maxime), szczególny (modo singularii) i wybitny (per excellentiam), istotowo (substantialiter) i trwale (continenter) pod postaciami eucharystycznymi ( $\mathrm{nr} 9$ i 55). - Część II (nr 16-48) podaje najpierw ogólne zasady odprawiania Mszy dla ludu (nr 16-24), a potem zasady bardziej szczegółowe dotyczące Mszy niedzielnej i w dni powszednie ( $\mathrm{nr} 25-30)$, komunii wiernych $(\mathrm{nr} 31-41)$ oraz Mszy w życiu i posługiwaniu Biskupa i kapłana (nr 42-48). Część III wreszcie (nr 49-67) mówi o celach przechowywania Najśw. Sakramentu (którymi są: udzielanie wiatyku, udzielanie Komunii św. poza Mszą św. i adoracja - nr 49-51), o miejscu przechowywania Eucharystii ( $\mathrm{nr}$ 52-57), o paraliturgicznych nabożeństwach eucharystycznych ( $\mathrm{nr}$ 58), o procesjach teoforycznych (nr 59), o wystawieniu Najśw. Sakramentu (nr 60-66) oraz o kongresach eucharystycznych (nr 67).

Aby uniknąć rozbieżności w sprawowaniu liturgicznych obrzędów eucharystycznych Konferencja Episkopatu Polski zatwierdziła tłumaczenie omawianej Instrukcji, a 11 września 1967 r. uchwaliła odpowiednie Zarządzenie wykonawcze, obowiązujące w całym kraju.

W niniejszych wskazaniach są uwzględnione tylko te przepisy zawarte w Instrukcji i w Zarządzeniu, które w mniejszym lub większym stopniu stanowią pewną nowość w dziedzinie prawno-liturgicznej ła więc $\mathrm{w}$ konsekwencji wprowadzają pewne zmiany $\mathrm{w}$ formach czci Eucharystii) i które są najważniejsze. We wskazaniach tych uwzględniono też komentarz, opracowany przez trzech konsultorów Posoborowej Rady dla realizacji Konstytucji o Św. Liturgii i równocześnie współtwórców Instrukcji, wydrukowany w miesięczniku „Notitiae" 1967, 261—288 (który jest organem tejże Rady).

\section{PRZEPISY OGÓLNO - KOŚCIELNE}

(niezależnie od decyzji lokalnej Władzy Duchownej)

1. W tym samym kościele nie należy odprawiać równocześnie różnych czynności liturgicznych, które rozpraszają uwagę zebranych. Stąd:

a) jednocześnie $\mathrm{z}$ zapowiedzianą i odprawianą Mszą dla ludu nie powinno się np. odmawiać brewiarza (ani chórowo, ani wspólnie), mówić kazania, udzielać chrztu, błogosławić małżeństw ( $\mathrm{mr} 17$ ); powyższy zakaz nie dotyczy oczywiście kazania głoszonego po ewangelii, a przed dalszym ciągiem Mszy św., ani ślubu zawieranego po kazaniu, a przed kontynuacją Najśw. Ofiary;

b) w niedziele i święta obowiązujące podczas Mszy dla ludu nie powinno się odprawiać innych Mszy św. (można jednak je odpra- 
wiać w oddzielnych kaplicach i bez udziału wiernych - Notitiae 1967, 272); tej samej zasady należy przestrzegać w miarę możności także w dni powszednie (nr 17);

c) wiernych trzeba usilnie zachęcać, by spowiadali się poza Mszą św., w której uczestniczą (nr 35):

2. W ciągu dnia należy odprawiać Msze św. o takiej porze oraz w takiej tylko liczbie, jakiej wymaga rzeczywista potrzeba wiernych i na jaką pozwalają możliwości kapłanów (nr 26).

3. $\mathrm{Na}$ mocy niniejszej Instrukcji wszystkim chorym oraz osobom w podeszłym wieku wolno udzielać Komunii św. o każdej porze dnia, choćby nawet ciężko nie chorowali ani nie groziło im niebezpieczeństwo śmierci ( $\mathrm{nr}$ 40).

4. Wystawienie Najśw. Sakramentu. a) Jeśli wystawienie trwa krótko, wtedy monstrancję lub puszkę stawia się na mensie; przy dłuższym zaś wystawieniu wolno używać tronu, byle nie był on umieszczony zbyt wysoko i daleko od ludu ( $\mathrm{nr} 62$ );

b) Warunkiem kilkugodzinnego (lub kilkudniowego) wystawienia Najśw. Sakramentu w monstrancji (z okazji tzw. Wieczystej Adoracji lub Czterdziestogodzinnego Nabożeństwa) jest nie tylko zezwolenie Ordynariusza miejsca, lecz także obecność odpowiedniej ilości adorujących ( $\mathrm{nr} 63$ n.). Jeżeli zaś takiej liczby nie można zapewnić, wtedy zapowiada się jedną lub dwie przerwy w ciągu dnia w ustalonych $\mathrm{z}$ góry godzinach; w takim wypadku repozycji i ekspozycji można dokonać (bez śpiewu) w następujący sposób: celebrans ubrany w komżę i stułę po krótkiej adoracji chowa Najśw. Sakrament, a później go wystawia i znów odprawia krótką adorację (nr 65); wolno też dokonać ekspozycji i repozycji ze śpiewem i okadzaniem, ale bez błogosławieństwa (Notitiae 1967, 288).

c) Bezwzględnie zabrania się wystawienia Najśw. Sakramentu po Mszy św. tylko dla udzieleniạ błogosławieństwa eucharystycznego (nr 66). Jeżeli zaś w związku z Mszą św. ma być uroczyste ( w monstrancji) i dłuższe wystawienie, (np. procesja teoforyczna, urządzana zwyczajowo w Polsce podczas odpustów i świąt parafialnych - por. Zarządzenie $\mathrm{nr}$ 11), wtedy w czasie przeistoczenia konsekruje się dwie hostie (jedną $\mathrm{z}$ nich $\mathrm{w}$ kustodii), na końcu Mszy opuszcza się błogosławieństwo kapłańskie i mówi się "Benedicamus Domino" (nr 60), po czym drugą Hostię wystawia się, śpiewając odpowiednią pieśń i okadzając Najśw. Sakrament (Notitiae 1967, 287).

d) Bez względu na jakiekolwiek tradycje i zwyczaje, nawet godne specjalnej wzmianki, zabrania się odprawiać Mszy św. nie tylko przy ołtarzu, lecz także w kościele, w którym jest wystawiony Najśw. Sakrament.

Gdy zaś wystawienie trwa cały dzień (lub kilka dni), wtedy na czas Mszy należy złożyć Najśw. Sakrament do tabernakulum (zachowując obrzędy podane w p. 4 nin. wskazań); wolno też w takim 
wypadku odprawić Mszę św. w kaplicy oddzielonej od nawy wystawienia, byle pewna grupa ludzi adorowawła wtedy Najśw. Sakrament (nr 61).

e) W kościołach i kaplicach należy utrzymać odprawianie np. w pierwsze piątki miesiąca jednej względnie dwóch Mszy św. wotywnych o Najśw. Sercu Jezusowym. Warunkiem ich celebry jest odmówienie w tym dniu specjalnych modlitw (pecularia pietatis exercitia) na cześć tegoż Najśw Serca, nie koniecznie w łączności z wotywą (por. Kodeks Rubryk $\mathrm{nr} 385$ a). Jeżeli jednak łączy się je ze Mszą św. i odprawia wobec wystawionej Eucharystii, ekspozycji wolno dokonać dopiero po ukończeniu Najśw. Ofiary (por. Zarządzenie $\mathrm{nr}$ 12).

\section{PRZEPISY UWARUNKOWANE UCHWAEA KONFERENCJI EPISKOPATU}

1. Na mocy zlecenia udzielonego w Instrukcji, Konferencja Episkopatu Polski postanawia, że wierni mają przyjmowac Komunię św. w pozycji klęczącej, z wyj. chorych, którym trudno stać oraz małych dzieci (por. Instr. nr 34 Zarządzenie $\mathrm{nr}$ 5).

2. Instrukcja przypomina, że znakiem obecności (signum praesentiae) Eucharystii w tabernakulum jest okrywające je konopeum, a lampka wieczna jest oznaka czci (signum honoris). Kompetentna Władza może jednak dopuścić inny sposób uwidaczniania wiernym obecności Najśw. Sakramentu. Na podstawie tego upoważnienia Konferencja Episkopatu Polski nakłada obowiązek używania konopeum względnie umieszczania na tabernakulum odpowiednich symbolów eucharystycznych (jak np. kłosy zboża i winogrona, baranek itp.) oraz stosowania czerwonej lampki wiecznej (por. Instrukcja. $\mathrm{nr}$ 57) Zarządzenie $\mathrm{nr}$ 17).

3. Na mocy upoważnienia, zawartego w omawianej Instrukcji $\mathrm{nr}$ 62, Konferencja Episkopatu Polski zezwala na śpiewanie przed błogosławieństwem eucharystycznym albo "Przed tak wielkim”, albo innej krótkiej polskiej pieśni eucharystycznej. Pieśń tę (z następującym po niej wersetem, responsorium i modlitwą) można opuścić w wypadku śpiewania przed błogosławieństwem hymnu „Ciebie, Boże chwalimy" oraz złączonych z nim wersetów i modlitwy (Zarządzenie $\mathrm{nr}$ 10).

\section{PRZEPISY UWARUNKOWANE ZEZWOLENIEM LOKALNEJ WEADZY DUCHOWNEJ}

1. Udzielanie Komunii św. poza Mszą św.

Wiernym, którzy słusznie o to proszą, należy udzielić Komunii św. w godzinach popołudniowych, nawet poza Mszą św. ( $\mathrm{nr} 33-\mathrm{czy}$ nabożeństwem), byle by ogólnie na to zezwolił Biskup rezyden- 
cjalny względnie delegowany przezeń Biskup Sufragan albo Wikariusz Generalny (na mocy Motu Proprio „Pastorale Munus” z 30 XI 1963, I, nr 4), albo Najwyższy Przełożony Zakonny (na mocy Reskryptu Pap. „Cum admotae” z 6 XI 1964, I, nr 1). Omawiana Instrukcja zaznacza jednakże, że udzielanie Komunii św. w takich wypadkach można poprzedzić krótkim nabożeństwem Słowa Bożego, o którym mowa w Instr. „Inter Oecumenici” z 26 IX 1964 w $\mathrm{nr} 37-39$.

Wymaganą słuszną przyczyną, uzasadniającą komunikowanie w godzinach popołudniowych poza Mszą św., a nawet poza nabożeństwem, jest $\mathrm{m}$. in. niemożność lub trudność jego odprawienia, uczestniczenia w nim, albo przyjęcia Eucharystii w czasie wskazanym przez Kodeks Prawa Kan. względnie w ciągu 1 godziny po ostatniej Mszy wieczornej (np. z powodu choroby, pracy, lub podróży).

Przez godziny popołudniowe rozumie się czas od 13,30 do 24; do udzielania zaś Komunii św. po północy upowáżnia kan. $867 \quad \S 4$ (ale tylko w poszczególnych wypadkach).

Do udzielenia nawet ogólnego zezwolenia na komunikowanie w związku z nabożeństwem popołudniowym w kościołach i kaplicach (szpitali, więzien, kolegiów), w których nie ma o tej porze Mszy św., upoważniła Ordynariuszy miejsca Kongr. Św. Oficjum już 21 III 1960 (por. np. Mies. Klny Archid. Pozn. 1960, 307-309).

Najwyższy Przełożony Zakonu lub Stowarzyszenia Kleryckiego na prawie papieskim (względnie subdelegowany przezeń Wyższy Przełożony) może (nawet ogólnie) zezwolić na udzielanie komunii św. poza Mszą i nabożeństwem o każdej porze dnia, ale tylko: a) w odniesieniu do kościołów i kaplic podległych sobie domów zakonnych (choćby kanonicznie nie erygowanych), b) swoim podwładnym, c) zakonnikowi, zakonnikom, (zakonnicom, które podlegają Przełożonemu zakonnemu) oraz wszystkim przebywającym przynajmniej przez jedną dobę $\mathrm{w}$ ich domach $\mathrm{z}$ racji gościny, choroby, studium lub służby.

Przez każdą porę dnia rozumie się czas od północy do północy (zgodnie z kan. $32 \S 1$ ).

Por.: Bujs: Facultates et privilegia Episcoporum concesse Motu Proprio Pastorale Munus, Roma 1964, 23-25; tenże: Facultates Religiosorum concesse Rescripto Pontificio diei 6 XI 1964, Roma 1967, 27-32; Rom it a: Facultates et privilegia a s. P. Paulo VI Episcopis concessa Litt. Ap. Pastorale Munus, Roma, 30-32; Ephemerides Liturgicae 1964, 159; Paroisse et Liturgie 1964, 340; ks. T. P a w lu k: Uprawnienia Biskupów... zawarte w M. Pr. „Pastorale Munus”, Studia Warmińskie, t. II, 1965, 303-306.

Warto dodać, że w całej Polsce obowiązuje w tej dziedzinie na- 
stępujące prawo partykularne, do dziś nieodwołane i niezależne od decyzji Władzy terytorialnej:

a) Kongr. Św. Oficjum 5 VI 1959 zezwoliła na udzielanie komunii św. w ciągu 1 godziny po ostatniej Mszy św. wieczornej i to nawet tym, którzy mogliby ją przyjąc w czasie przewidzianym przez K.P.K. lub w związku z Mszą św. popołudniową (albo w związku z popołudniowym nabożeństwem; por. np. Mies. Klny Archid. Pozn. 1959, 314 n.).

b) Ta sama Kongregacja 2 XII 1959 zezwoliła na udzielanie komunii św. w godzinach popołudniowych (niezależnie od nabożeństwa) tym, którzy nie mogą jej przyjąć ani w czasie przewidzianym przez K.P.K., ani podczas Mszy św. popołudniowej, ani w ciągu 1 godziny po ostatniej Mszy św. wieczornej (ani w związku z popołudniowym nabożeństwem; por. tenże Mies. Klny 1960, $30 \mathrm{nr} ., 315)$.

2. Udzielanie komunii św. pod obiema postac i a m i (nr 32).

Obrzęd udzielania komunii św. pod obiema postaciami, ogłoszony przez Kongregację Obrzędów 7 marca 1965 r., nr 1 wylicza w jedenastu punktach wiernych, którym (za zezwoleniem Biskupa rezydencjalnego) wolno w ten sposób przyjmować Eucharystię. Instrukcja z 25 maja 1967 r. powiększa grono uprawnionych do tego osób i dla większej jasności wylicza wszystkich taksatywnie. Wyliczenie to jest podane w dodatku do niniejszych wskazań., zawierającym przekład i komentarz do „Obrzędu udzielania komunii św. pod obiema postaciami".

3. Komunia św. tylko pod postacią wina.

Tylko pod postacią wina wolno (w razie konieczności) udzielić Eucharystii tym, którzy nie mogą jej przyjąć pod postacią chleba, byle Biskup rezydencjalny na to zezwolił. W takim wypadku można też (za zgodą Ordynariusza miejsca) odprawić w domu chorego Mszę św. Jeżeli w jego domu Mszy św. się nie odprawia, wtedy przechowuje się Krew Pańską w kielichu odpowiednio przykrytym i umieszczonym w tabernakulum; do chorego zaś zanosi się Postać Wina w naczyniu tak zamkniętym, by nie było niebezpieczeństwa rozlania ( $\mathrm{nr} 41)$.

Eucharystii tylko pod postacią wina udziela się w jeden $\mathrm{z}$ najbardziej odpowiadających danej sytuacji sposobów podanych w „Obrzędzie... komunii pod obiema postaciami (albo wprost z naczynia, albo przez rurkę, albo przy pomocy łyżeczki; szczegóły por. cyt. Obrzęd nr 3 a. b, 5 c. d, 9 b, 11).

4. Koncelebra.

a) Kto w tym samym kościele pragnie odprawić Mszę św., wtedy kiedy ma być inna Msza dla ludu, niech ją koncelebruje, jeśli oczywiście jest na to zezwolenie (nr 17). 
b) Kapłani, którzy koncelebrują z racji wspólnie prowadzonego życia, lub którzy pracują tam gdzie odbywa się zjazd kapłanów, niech zachęcają przybyłych konfratrów do koncelebry; kompetentni zaś Przełożeni niech w takich wypadkach na koncelebrę chętnie pozwalają, a nawet niech ją popierają (nr 17).

c) Kapłani, którzy biorą udział we Mszy św. (np. we W. Czwartek, albo podczas rekolekcji czy kongregacji dekanalnej), nie powinni przyjmować komunii św. tak jak świeccy, lecz powinni tę Mszę koncelebrować, jeśli oczywiście jest na to zezwolenie (nr 43; w W. Czwartek zezwolenia nie potrzeba).

\section{PRZEPISY UWARUNKOWANE ZEZWOLENIEM STOLICY APOSTOLSKIEJ}

Tam, gdzie Stolica Apostolska zezwoliła, by przez udział we Mszy odprawianej w sobotę lub w dzień przed świętem obowiązującym zadośćuczynić drugiemu przykazaniu kościelnemu, należy tę Mszę celebrować wieczorem, o godzinie wyznaczonej przez Ordynariusza miejsca (nie wcześniej jak o 13,30), używając formularza niedzielnego (względnie świątecznego), wygłaszając homilię (oraz odmawiając modlitwę powszechną, jeśli ją wprowadziła Konferencja Episkopatu). W przeddzień jednak uroczystości Zesłania Ducha Św. bierze się w takim wypadku formularz z Wigilii, dodając "Credo"; podobnie $w$ przeddzień Bożego Narodzenia bierze się formularz z Wigilii, dodając "Gloria”, "Alleluja” po graduale i „Credo", mówiąc prefację z B. Narodzenia oraz używając szat białych; w Wigilię zaś Pachalną zachowuje się $\mathrm{w}$ takim wypadku wszystkie dotychczasowe przepisy.

Wierni, którzy w powyższy sposób wypełniają drugie przykazanie kościelne, podczas wspomnianej wieczornej Mszy św. mogą komunikować choćby nawet rano przystąpili do Stołu Pańskiego (nr 28).

Iłówiec k. Poznania

KS. ROMAN MICHAŁEK 